\title{
CRUDE POLYSACCHARIDES EFFECT OF Coriolus versicolor ON Mycobacterium fortuitum-INDUCED IMMUNE DYSFUNTION IN MICE
}

\author{
Sri Puji Astuti Wahyuningsih ${ }^{1 a^{*}}$, Dwi Winarni ${ }^{1 \mathrm{~b}}$, Win Darmanto ${ }^{1 \mathrm{c}}$, Sugiharto ${ }^{1 \mathrm{~d}}$, Elma \\ Sakinatus Sajidah ${ }^{1 e}$, and Baiq Naili Dewi Atika ${ }^{1 f}$ \\ 1Department of Biology, Faculty of Science and Technology, Airlangga University, Surabaya 60115, INDONESIA.

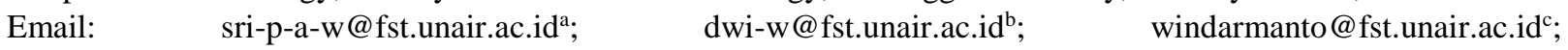 \\ sugiharto@fst.unair.ac.id ${ }^{\mathrm{d}}$; elmasakinatus@gmail.com; baiq.naili.dewi-2017@fst.unair.ac.id ${ }^{\mathrm{g}}$ \\ *Corresponding Author: sri-p-a-w@fst.unair.ac.id \\ Submitted: $27^{\text {th }}$ December $2018 \quad$ Accepted: $9^{\text {th }}$ July 2019 \\ Published: $30^{\text {th }}$ November 2019
}

DOI: https://doi.org/10.22452/mjs.sp2019no3.4

\begin{abstract}
Coriolus versicolor contains crude polysaccharides which have $\beta$-glucan active ingredients. It can activate granulocyte, monocyte, and macrophage. Administration of crude polysaccharide of $C$. versicolor against bacterial infection is hypothesized to increase immune response. This study assessed the crude polysaccharides activity of $C$. versicolor in improving immune response after induction of non-tuberculosis mycobacteria, Mycobacterium fortuitum. Animal model was female mice strain BALB/c aged 8-10 weeks. A crude polysaccharide of $C$. versicolor was administered before and/or after the bacteria infection for 10 days at a dose of $50 \mathrm{mg} / \mathrm{kg}$ body weight. Mice exposure to $M$. fortuitum was performed twice at a dose of $0.5 \mathrm{Mc}$. Farland. After crude polysaccharides treatment, both serum and peritoneal fluid were isolated. All data collected were analyzed statistically using ANOVA and Duncan test. Oral administration of crude polysaccharide was found to increase phagocyte number $(\mathrm{P}<0.05$, from crude polysaccharides administration before-after infection), improve phagocytic activity $(\mathrm{P}<0.05$, from crude polysaccharides administration before infection), raise both IFN- $\gamma$ and antibody level $(\mathrm{P}<0.05$, from crude polysaccharides administration after and before-after infection), and it caused TNF- $\alpha$ levels to tend to a normal concentration ( $>>0.05$, TNF- $\alpha$ levels after crude polysaccharides administration were relatively the same as controls). Administration of crude polysaccharides of $C$. versicolor could enhance non-specific immune response, specific immune response, and pro-inflammatory cytokine in mice infected by $M$. fortuitum. These results suggested that crude polysaccharides of $C$. versicolor may be applied as an effective immunostimulatory agent.
\end{abstract}

Keywords: Coriolus versicolor, crude polysaccharide, Mycobacterium fortuitum, immune function

\section{INTRODUCTION}

Mycobacterium fortuitum is one of the non-tuberculous mycobacteria that infect the skin, soft tissue, lungs, lymph nodes, and joints in the postoperative section (Atkins and Gottlieb, 2014). The infection is frequently caused by direct or indirect exposure of the wound to contaminated tap water and air (Scheld, 2014). The most frequently reported infections were postsurgical, primary cutaneous, and pulmonary (Lahiri et al., 2009). 
The body possesses an immune system against pathogens infecting both cells and tissue. Epithelial cells are the first line of defense as natural immunity. It can produce chemokine and cytokine that activate phagocytic cells to destroy pathogens and infected cells (Paul, 2013). Natural immunity consists of various components, such as a phagocyte, NK cell, mast cell, eosinophil, neutrophil, complementary component, and proinflammatory cytokines, for example, interferon (IFN)- $\gamma$, interleukin (IL)-1, IL-6, IL-12, IL-18, and tumor necrosis factor (TNF)- $\alpha$ (D'Elios et al., 2011).

In Indonesia, Coriolus versicolor mushrooms are abundant and have not been utilized. Some studies state that $C$. versicolor fungus contains polysaccharides, specifically polysaccharide krestin (PSK) that was previously found to possess immunomodulatory activity (Fritz et al, 2015). The carbohydrate compounds consist of mannose, xylose, galactose, in addition to fructose in polysaccharide peptide (PSP) or arabinose and rhamnose in PSK (Ng, 1998). The PSP is typically isolated by boiling COV-1 mycelia or fruiting bodies in water, followed by precipitation in ethanol (Kotsirilos et al., 2011, Saleh et al., 2017). Polysaccharide krestin is composed of $\beta$ glucan attached to proteins. Structural analysis revealed that $\beta$-glucan from $C$. versicolor has a linear $\alpha$-glucan chain composed of only $(1 \rightarrow 6)-\alpha-D-G l c p$. It has a glucose homopolymer associated with glycoside bond (Awadasseid et al., 2017). It can interact with immune cells to produce both cytokines and endogenous antioxidant (Chen and Seviour, 2007) so to improve immune response (Meena et al., 2013). Macrophage as the non-specific immune cell can degrade $\beta$-glucan into smaller fragments and then released into lymphoid tissue, such as bone marrow, lymph, and lymph nodes (Goodridge et al., 2009).
Beta-glucan fragment activated granulocyte, monocyte, macrophage, natural killer (NK) cell, and dendritic cell passing through lymphoid tissue by binding to dectin-1, Toll-like receptor (TLR)-2/6, and complement receptor (CR)-3 (Chan et al., 2009). The interaction of immune cells and $\beta$-glucan triggered macrophage and monocyte to produce various cytokines (TNF $\alpha$, IL-2, IL-10, and IL-12) (Taylor et al., 2004). These cytokines stimulated granulocyte monocyte colony-stimulating factor (GM-CSF) and monocyte colonystimulating factor (M-CSF) in the bone marrow to improve the proliferation of granulocyte and monocyte, thus increasing the phagocytosis process. The rise of phagocytosis level would produce more nitric oxide (Ushach and Zlotnik, 2016). Cytokine interacted with CR3 to induce NK cells to lyses pathogen-infected cells, meanwhile dendritic cells produced cytokine and triggered $\mathrm{T}$ cell proliferation. Cytokine and T-cell activity, then triggered B-cell to produce antibody. Beta-glucan could also modulate Th1 cells to secrete IFN- $\gamma$ via MHC II mechanism (Chan et al., 2009).

PSK extracted from $C$. versicolor extract had been studied previously as treatment for cancer due to its presumed immunomodulatory effect (Fritz et al, 2015). However, research on the use of polysaccharides from $C$. versicolor to increase immunity against bacterial infection is still scant. Hence, current research was conducted to evaluate the immunomodulatory activity of $C$. versicolor hot water extract against bacterial infection. The present study explored this effect by evaluating phagocyte numbers, phagocytic activity, cytokine production, and antibody level in mice exposed to $M$. fortuitum. 


\section{MATERIALS AND METHODS}

\subsection{Preparation of bacteria}

M. fortuitum was obtained from Balai Besar Laboratorium Kesehatan, East Java, Indonesia and grown on solid medium at room temperature. Subsequently, $M$. fortuitum was subcultured into $20 \mathrm{~mL}$ liquid medium for 2 days. A liquid medium containing bacteria were centrifuged at 3000 $\mathrm{rpm}$ for $10 \mathrm{~min}$. The supernatant was discarded, while the pellet was diluted with saline solution at a concentration of $0.5 \mathrm{Mc}$. Farland.

\subsection{Preparation of crude polysaccharides from $C$. versicolor}

C. versicolor were collected in June 2016 from teak forests in the Lamongan region, East Java. It has been identified by the Indonesian Institute of Sciences or Lembaga Ilmu Pengetahuan Indonesia (LIPI) Purwodadi, Indonesia (LIPI-14010). C. versicolor $(4 \mathrm{~kg}$ ) was air-dried before cut into small pieces and dried in oven at $40^{\circ} \mathrm{C}$ for $24 \mathrm{~h}$. Mushroom pieces $(1 \mathrm{~kg})$ were then ground into powder $(500 \mathrm{~g})$. The mushroom powder $(200 \mathrm{~g})$ was macerated twice with 3 $\mathrm{L}$ and $1 \mathrm{~L}$ of hot water at $80-95^{\circ} \mathrm{C}$ for $2-3$ hours. Furthermore, the mushroom extract was filtered using Whatman paper No. 41, vacuum and Buchner funnel. Then, the supernatant was lyophilized. The lyophilized mushroom $(20 \mathrm{~g})$ was precipitated by ammonium sulfate $90 \%$ for $24 \mathrm{~h}$ at $4^{\circ} \mathrm{C}$, followed with centrifuge at $9000 \mathrm{rpm}$ for 20 min at $4^{\circ} \mathrm{C}$. The precipitated material was dissolved with $10 \mathrm{~mL} \quad \mathrm{dH}_{2} \mathrm{O}$, dialyzed overnight and lyophilized to freeze dry. This process produced a powder containing the crude polysaccharides (Cui and Christi, 2003).

\subsection{Measurement of the total polysaccharides}

The total polysaccharides contents were determined using the phenol-sulfuric acid. The $1.5 \mathrm{~g}$ of the powder containing the crude polysaccharides was added to $50 \mathrm{~mL}$ of $\mathrm{dH}_{2} \mathrm{O}$ as a stock solution. The stock solution $(10 \mu \mathrm{L})$ was added to $90 \mu \mathrm{L} \mathrm{dH}_{2} \mathrm{O}$ and $50 \mu \mathrm{L} \mathrm{5 \%}$ phenol. The solution was homogenized for $1 \mathrm{~min}, 2 \mathrm{~mL}$ of sulfuric acid was then added to the solution before it was incubated for $10 \mathrm{~min}$ at room temperature. The blank solution was made from $50 \mu \mathrm{L} 5 \%$ phenol and $100 \mu \mathrm{L}$ of distilled water. Absorbance or optical density (OD) was measured at $490 \mathrm{~nm}$. The OD value obtained was 1.93. It was calculated based on a standard curve $(\mathrm{Y}=$ $0.008 \mathrm{X}+0.079$, $\mathrm{Y}$ was $\mathrm{OD}$ value $\mathrm{D}, \mathrm{X}$ was the polysaccharides contents), which resulted $231.4 \mathrm{mg} / \mathrm{mL}$.

\subsection{Animal model and experimental design}

All procedures involving animal care were approved by the Animal Care and Use Committee (ACUC) of Veterinary Faculty, Airlangga University, Surabaya, Indonesia, number 654-KE. The mice used as animal model were placed in ventilated cages given condition of 12-h light/12-h dark cycle. Thirty-six female BALB/c mice (8-10 weeks; $30-40 \mathrm{~g}$ ) were acclimated for a week before divided into 6 groups: normal control, without crude polysaccharide administration and $M$. fortuitum exposure (K), positive control with administration of crude polysaccharide $(\mathrm{K}+)$, negative control which exposed to $M$. fortuitum and without polysaccharide administration (K-), and $\mathrm{P} 1$, P2, P3 with administration of crude polysaccharide before, after, and both before-after exposure of $M$. fortuitum respectively. Crude polysaccharides were administrated at a dose of $50 \mathrm{mg} / \mathrm{kg}$ body weight by peroral gavage for 10 days. Exposure of bacterial infection was 
performed 2 times intraperitoneally with 2 weeks interval.

\subsection{Collection of serum sample}

After one week of crude polysaccharide administration, blood was taken from mice by cardiac puncture. Blood was left to coagulate at room temperature for $2 \mathrm{~h}$ before centrifuging at $3000 \mathrm{rpm}$ for 10 min. Serum was isolated and used to measure cytokines (IFN- $\gamma$ \& TNF- $\alpha$ ) and antibody level.

\subsection{Collection of peritoneal fluid}

The intraperitoneal cavity of mice was injected with $0.2 \mathrm{~mL}$ of $M$. fortuitum suspension. One hour after the injection, mice were anesthetized using ketamine. Saline solution containing 10\% EDTA (2 $\mathrm{mL}$ ) then injected into the intraperitoneal cavity. Finally, 0.5-1 mL intraperitoneal fluid was taken using a syringe to evaluate the number of phagocytes and phagocytic activity.

\subsection{Phagocyte number evaluation and phagocytic activity assay}

As much as $20 \mu \mathrm{L}$ peritoneal liquid was diluted with $100 \mu \mathrm{L}$ Turk solution and resuspended for 10 times until it was well mixed. The solution was dripped onto the right and left margins of the hemocytometer counting chamber, then phagocyte number was counted. Meanwhile, $70 \mu \mathrm{L}$ peritoneal fluid was smeared on a slide glass and airdried. The smear was stained using $0.01 \%$ carbol fuchsin dye for $30 \mathrm{~min}$. Slides were passed by fire over a Bunsen burner until it was smoked but not boiled. The smear was then cooled down for about 3-5 min. It was next washed in running water and the remaining color was rinsed with $0.1 \% \mathrm{HCl}$ until no carbol fuchsin dye found left. The smear was washed again with running tap water before counterstained using methylene blue for 3-5 min. Finally, the smear was rinsed using water and then left to dry. Phagocytic activity was measured from the percentage of phagocytes found ingesting bacteria out of 100 phagocytes count.

\subsection{Serum cytokines assay}

Cytokines measured in this study were IFN- $\gamma$ and TNF- $\alpha$. The level of both cytokines was measured using the Sandwich-ELISA method. Microplate initially was coated with either anti-IFN- $\gamma$ or anti-TNF- $\alpha$. As much as $100 \mu \mathrm{L}$ serum was diluted with assay buffer (1:1) then filled into wells and incubated overnight at $4{ }^{\circ} \mathrm{C}$. Microplate was emptied over and washed 3 times with washing buffer. Next, $50 \mu \mathrm{L}$ biotin-conjugate was added into each well. Microplate was incubated at room temperature $\left(18-25^{\circ} \mathrm{C}\right)$ covered with aluminum foil for $2 \mathrm{~h}$ while it was shaken at $200 \mathrm{rpm}$. Microplate was then rinsed 3 times with washing buffer. Streptavidin-HRP solution was added into each well, except for blank well. The plate was incubated again at room temperature, covered with aluminum foil for $1 \mathrm{~h}$. Microplate was rewashed 3 times using washing buffer before $100 \mu \mathrm{L}$ TMB substrate solution was added into each well. The plate was incubated lastly at room temperature for $10 \mathrm{~min}$ until the color was formed. A positive reaction was indicated by a dark blue color. The reaction was discontinued by adding $100 \mu \mathrm{L}$ stop solution into each well. The value of optical density (OD) was determined using an ELISA reader at $450 \mathrm{~nm}$ wavelength. Both IFN- $\gamma$ and TNF$\alpha$ levels were converted from OD value using a standardized curve.

\subsection{Antibody level assay}

The antibody level was measured using indirect ELISA method. Antibody level was determined from OD value. A total of $100 \mu \mathrm{L}$ bacteria firstly coated onto 96- 
well microplate and incubated overnight at $4^{\circ} \mathrm{C}$. Blocking was performed by adding 200 $\mu \mathrm{L} 10 \%$ BSA solution before microplate was incubated for $15 \mathrm{~min}$ at room temperature. Each well was then added $100 \mu \mathrm{L}$ primary antibody and incubated for $1 \mathrm{~h}$ at room temperature. The microplate was washed 3 times with washing buffer, then $100 \mu \mathrm{L}$ of 1 $\mu \mathrm{g} / \mathrm{mL}$ conjugate of $\mathrm{IgG}$ goat anti-mouse was added into each well. Microplate was incubated again for $1 \mathrm{~h}$ at room temperature before it was rinsed 3 times using a washing buffer. Finally, each well was added $100 \mu \mathrm{L}$ ABTS substrate and left to react. The reaction was stopped by adding $100 \mu \mathrm{L}$ stopping solution. The OD value of antibody was determined using a microplate reader at $405 \mathrm{~nm}$ wavelength.

\subsection{Statistical analysis}

All values are expressed as mean \pm standard error (SE). Statistical analysis was performed using one-way ANOVA followed by Duncan multiple comparison test. All analysis was performed using IBM SPSS Statistics 24 software. P-values less than 0.05 were considered statistically significant.

\section{RESULTS AND DISCUSSION}

\subsection{Effect of crude polysaccharides of $C$. versicolor on the number of phagocytes}

Effect of crude polysaccharides of $C$. versicolor on the number of phagocytes was presented in Fig. 1. The number of phagocytes in $\mathrm{K}, \mathrm{K}+, \mathrm{K}-, \mathrm{P} 1, \mathrm{P} 2$, and $\mathrm{P} 3$ groups were $99 \pm 25,90 \pm 29,100 \pm 25,88 \pm 44$, $86 \pm 18$, and $180 \pm 37 \quad\left(\times 10^{5} \mathrm{cell} / \mathrm{mm}^{3}\right)$, respectively. It was significantly increased in the P3 group compared to other groups $(\mathrm{P}<0.05)$. Meanwhile, the phagocyte number from P1 and P2 was found to be relatively similar and did not show a significant difference compared to $\mathrm{K}, \mathrm{K}+$, and $\mathrm{K}$ $(\mathrm{P}>0.05)$.

Phagocytes are an important part of the body's defense system and counting the number of phagocytes is a valid method to evaluate immune function (Abbas et al., 2014). Phagocytic cells of the immune system consist predominantly of macrophage and neutrophil. These cells represent major cellular effectors of nonspecific host defense and inflammation. Through their ability to phagocytize foreign substances and release cytotoxic and proinflammatory mediators, neutrophil and macrophage protect the body from a wide array of pathogens and xenobiotic while also play a central role in the host response towards tissue injury (Laskin et al., 2010). A decrease in the number of phagocytes causes disorders of certain immune factors, leading to a decrease in immune function. The administration of Schisandra polysaccharides significantly inhibits the decrease in phagocytes in mice immune compromised with cyclophosphamide (Yu et al, 2018). 


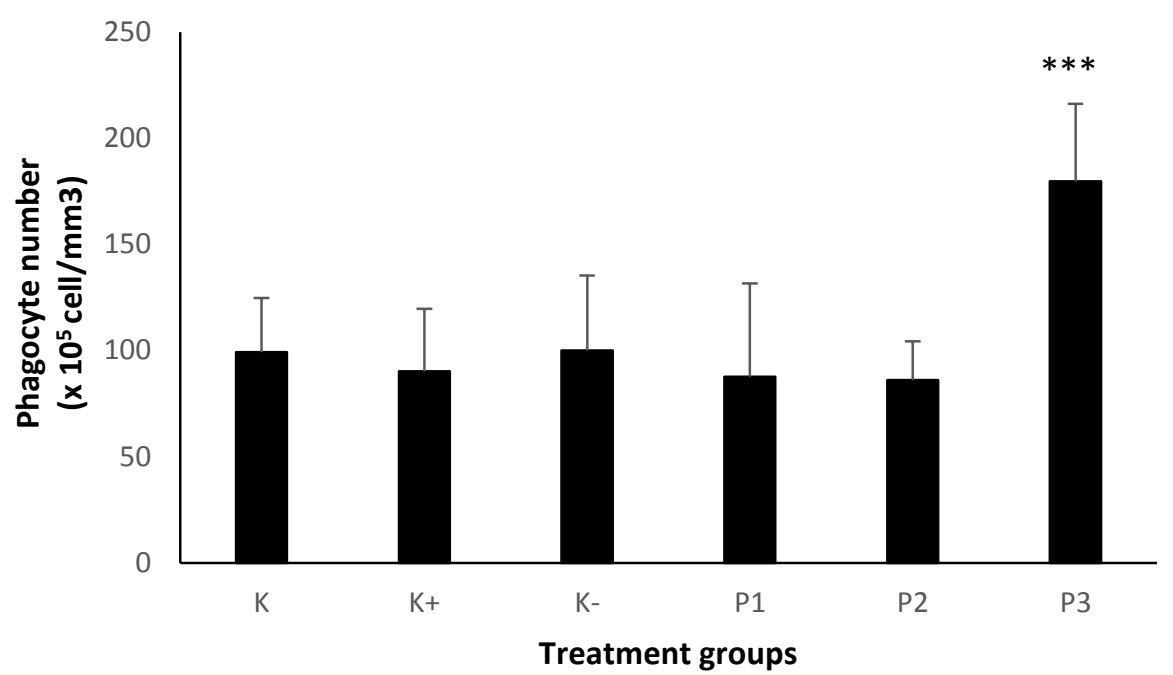

Figure 1. Effect of crude polysaccharides of $C$. versicolor on number of phagocyte. K: normal control; $\mathrm{K}+$ : positive control; $\mathrm{K}-$ : negative control; P1, P2, and P3: treated with $C$. versicolor extract before, after, and before-after exposure of $M$. fortuitum. ***) $\mathrm{P}<0.05$, compared to $\mathrm{K}, \mathrm{K}+$, and K-.

The results of the present study indicated that crude polysaccharide of $C$. versicolor significantly inhibits the decrease in the number of phagocytes in mice immune dysfunction induced $M$. forfoitum. The number of phagocytes increased in groupadministered $C$. versicolor extract beforeafter bacterial infection (P3 group). Saleh et al. (2017) have reported that polysaccharide extracted from $C$. versicolor was able to enhance the proliferation of leukocyte. $\mathrm{Ng}$ (1998) stated that PSK activity is characterized by their ability to increase white blood cell counts, IL-2 production and delayed-type hypersensitivity reactions. Also, the treatment of healthy nude mice (i.p.) with $C$. versicolor extract for 2 weeks resulted in an increased white blood and neutrophil count (Sze and Chan, 2009).

\subsection{Effect of crude polysaccharides of $C$. versicolor on phagocytic activity}

Effect of crude polysaccharides of $C$. versicolor on phagocytic activity was presented in Fig. 2. The phagocytic activity was significantly elevated in both P1 $(43.6 \pm 15.3 \%)$ and $\mathrm{P} 2(40.0 \pm 6.2 \%)$, which were given extracts before and after bacterial infection compared to positive $(25.4 \pm 8.8 \%)$ and negative control $(30.6 \pm 8.4 \%)(\mathrm{P}<0.05)$. The highest increase of phagocytic activity was found in the P1 group. Meanwhile, P3 $(25.7 \pm 6.3 \%)$ did not show a significant difference compared to normal $(24.6 \pm 5.2 \%)$, positive, and negative control $(\mathrm{P}>0.05)$.

Phagocytes are immunocompetent cells that able to destroy microbes by phagocytosis. When the body is infected by the pathogen, phagocytes will be activated due to lipopolysaccharide (LPS) composing bacterial cell wall. Pathogen entering the body will be bound by surface receptors of the phagocyte. Further, phagocyte membranes will surround the pathogen and form phagosomes. It will fuse with lysosomes to form phagolysosomes in which reactive oxygen species (ROS), nitric oxide (NO) and lysosomal enzyme are secreted to destroy bacterial wall and DNA (Abbas et al., 2014). 


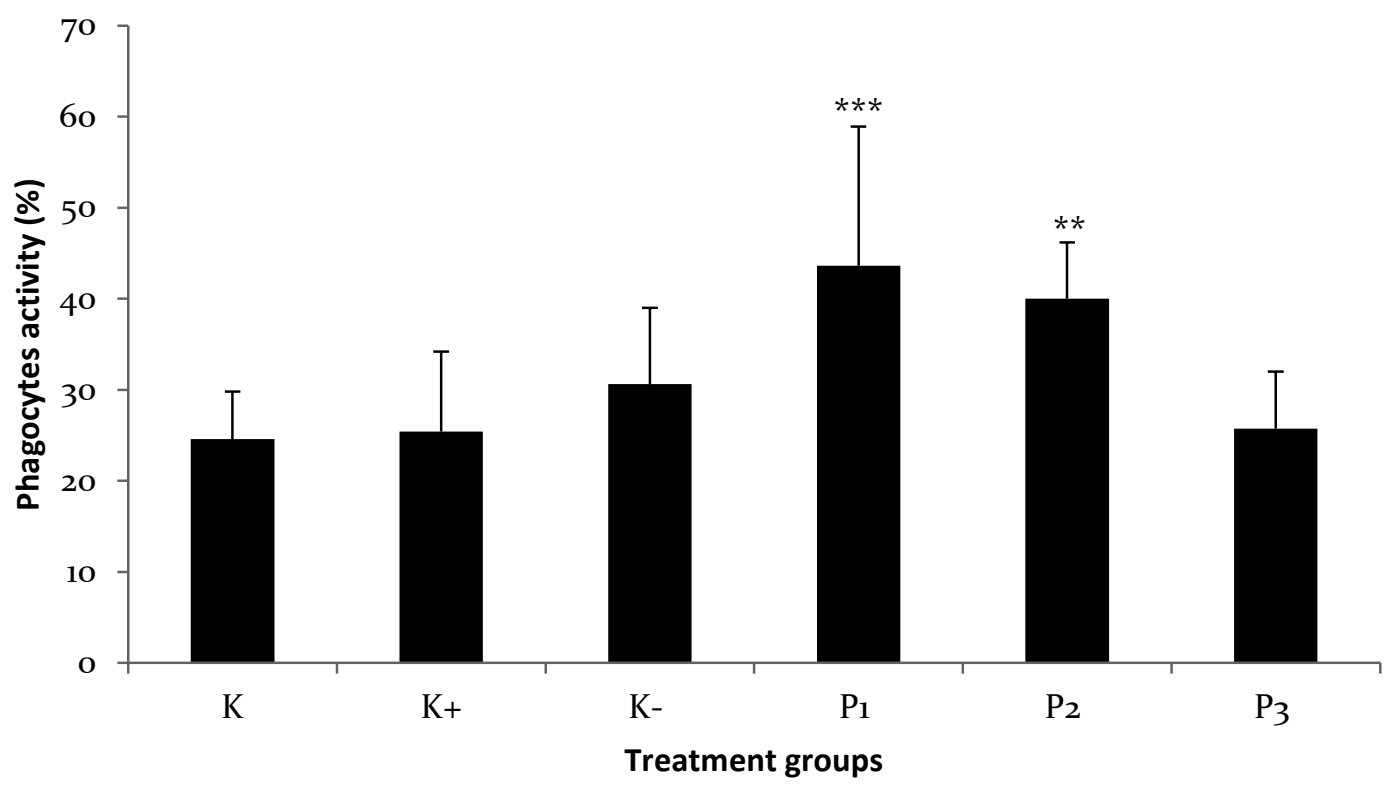

Figure 2. Effect of crude polysaccharides of C. versicolor on phagocytic activity. K: normal control; K+: positive control; K-: negative control; P1, P2, and P3: treated with Coriolus versicolor hot water extract before, after, and before-after exposed to M. fortuitum. **) $\mathrm{P}<0.05$ compared to $\mathrm{K}$ and $\mathrm{K}+$. ***) $\mathrm{P}<0.05$ compared to $\mathrm{K}, \mathrm{K}+$, and $\mathrm{K}-$.

Phagocytic activity was found to increase in groups infected by $M$. fortuitum (K-, P1, P2, and P3). This infection would induce proliferation of phagocytic cells, then induction occurred again when $C$. versicolor extract was administrated before and/or after bacterial infection. Saleh et al. (2017) stated that binding of PSK to any/all of Dectin-1, CR3, or TLRs on macrophages leads to the activation of genetic events that increase phagocytic activity and induces the production of oxidative radicals. Then, the phagocytosis process will occur against the antigen from the outside. Vetvicka and Oliveira (2014) reviewed that $\beta$-glucan content in carbohydrate was considered a non-specific stimulator of cellular immunity, particularly macrophage. Chen et al. (2008) reported that $\beta$-glucan was also found to upregulate phagocytosis of macrophage after bacterial infection in chicken. Novak and Vetvicka (2008) research showed that $\beta$ glucan increased both proliferation of macrophage and cytokine in bone marrow, thus more phagocytes were recruited to the infected organs. Wahyuningsih et al. (2016) stated that polysaccharide krestin from $C$. versicolor increased both phagocytic activity and capacity on Mus musculus exposed to Pseudomonas aeruginosa. A crude polysaccharide from okra pods could also enhance phagocytic activity (Wahyuningsih et al., 2018).

\subsection{Effect of crude polysaccharides of $C$. versicolor on cytokines production}

Serum IFN- $\gamma$ level was found to increase significantly both in P2 and P3, in which $C$. versicolor hot water extract was administrated with extract after $(377.8 \pm 68.0 \mathrm{pg} / \mathrm{ml})$ and before-after $M$. fortuitum infection $(264.9 \pm 122.6 \mathrm{pg} / \mathrm{ml})$ compared to $\mathrm{K}$ and $\mathrm{K}+$, but did not significantly differ compared to the negative control (K-) $(\mathrm{p}>0.05)$. TNF- $\alpha$ level from P1, P2, and P3 did not indicate a significant difference compared to either normal, positive, or negative control 
( $>0.05$ ). A slight decrease of serum TNF$\alpha$ level was found in P1, P2, and P3, but did not show significant difference statistically. Effect of crude polysaccharides of $C$. versicolor on cytokines production was presented in Table 1.

Nontuberculosis mycobacteria (NTM)-related infection is acquired through environmental exposure. There had been no documented case of human-to-human or animal-to-human transmission. An abnormal immune system, for example, declined $\mathrm{CD}^{4+} \mathrm{T}$ cell count or macrophage dysfunction, cause susceptibility to NTM infection. Similar to other intracellular pathogens, NTM is phagocytized and destroyed by normal functioning macrophage in response to IFN- $\gamma$ production, which in turn was upregulated by interleukin-12 (IL-12) (Griffith et al., 2007). In this study, $M$. fortuitum infection also induced IFN- $\gamma$ release. After the administration of $C$. versicolor extract, the IFN- $\gamma$ level was increased, especially in P2 and P3.
Tumor necrosis factor (TNF)- $\alpha$ is a mediator of the acute inflammatory response to bacteria. Large amounts of this cytokine may be produced during infections with gram-negative and gram-positive bacteria. The concentration of serum TNF- $\alpha$ may be predictive of the outcome of severe bacterial infections (Abbas et al., 2014). TNF- $\alpha$ critical role in the control of infection by intracellular organisms (Keane, 2004). IFN$\gamma$ and IL-12 control mycobacteria through upregulated TNF- $\alpha, \quad$ produced predominantly by monocytes/macrophages. Increased risk of NTM infection presents during TNF inhibitor therapy. In this study, TNF- $\alpha$ level was relatively the same across experimental groups. TNF- $\alpha$ level from the group with bacterial infection alone (K-) was slightly higher compared to groups given polysaccharide from $C$. versicolor extract before, after, and before-after infection ( $\mathrm{P} 1$, P2, P3). This could cause septic shock. Low levels of TNF- $\alpha$ on P1, P2, and P3 were used for macrophage activation and local inflammation.

Table 1. Effect of crude polysaccharides from C. versicolor on cytokines production

\begin{tabular}{ccc}
\hline Group & IFN- $\gamma$ level $(\mathrm{pg} / \mathrm{mL})$ & TNF- $\alpha$ level $(\mathrm{pg} / \mathrm{mL})$ \\
\hline K & $39.5 \pm 22.8$ & $842,7 \pm 244,97$ \\
K+ & $31.0 \pm 9.9$ & $613,7 \pm 240,17$ \\
K- & $269.6 \pm 125.6$ & $808,0 \pm 277,85$ \\
P1 & $147.9 \pm 103.2$ & $543,3 \pm 292,04$ \\
P2 & $377.8 \pm 68.0^{* *}$ & $666,1 \pm 141,69$ \\
P3 & $264.9 \pm 122.6^{* *}$ & $536,1 \pm 281,67$
\end{tabular}

K: normal control; $\mathrm{K}+$ : positive control; $\mathrm{K}-$ : negative control; P1, P2, and P3: treated with C. versicolor hot water extract before, after, and before-after exposed to $M$. fortuitum. Values are presented as mean $\pm \mathrm{SD}(\mathrm{n}=6) . * *) \mathrm{P}<0.05$ compared to $\mathrm{K}$ and $\mathrm{K}$ 
From a previous study, crude polysaccharides extracted from okra pods were able to increase TNF- $\alpha$ level at low doses but inhibited it at a high dose (Wahyuningsih et al., 2018). The supplementation $\quad \beta(1-3)(1-6)$-D-glucan significantly lowered the TNF- $\alpha$ levels after lipopolysaccharide (LPS) challenge (Vetvicka and Oliveira, 2014). Detrick et al. (2008) and Abbas et al. (2014) mentioned that TNF- $\alpha$ worked on both leukocyte and endothelial. At a moderate level, it played a role in acute inflammatory response. High TNF- $\alpha$ level could cause pathological abnormality in septic shock, a lifethreatening condition caused when bacteria enter the bloodstream, is mediated in large part by this cytokine.

\subsection{Effect of crude polysaccharides of $C$. versicolor on antibody level}

Optical Density (OD) value of antibody showed an antibody level indirectly. The higher OD value, the higher antibody level. Antibody level was found to significantly rise in both P2 $(0.858 \pm 0.180)$ and P3 $(0.856 \pm 0.104)$ compared to normal $(0.418 \pm 0.051)$, positive $(0.429 \pm 0.029)$, and negative $(0.515 \pm 0.069)$ control groups $(\mathrm{P}<0.05)$. The highest increase of antibody level was shown by P2, which was administered with extract after bacterial infection. Meanwhile, slightly decreased of antibody level was found from P1 $(0.448 \pm 0.046)$ which was not different statistically compared to normal, positive, and negative control respectively. Effect of crude polysaccharides of $C$. versicolor on antibody level was presented in Fig. 3.

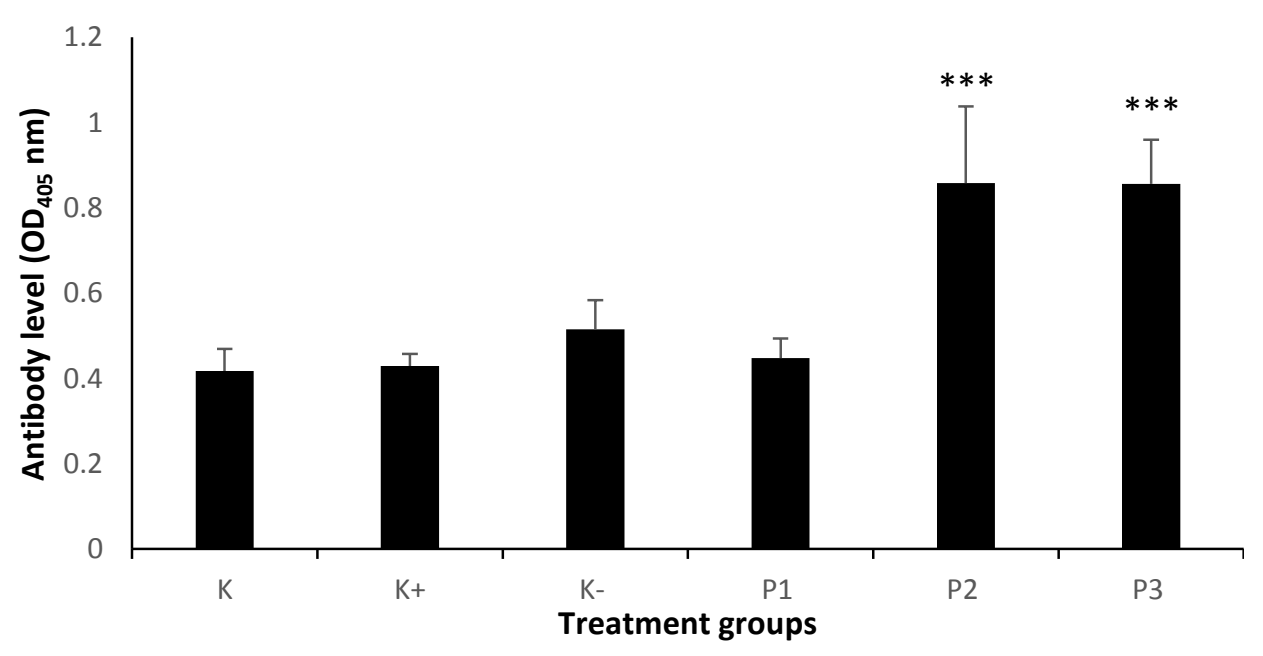

Figure 3. Effect of crude polysaccharides of C. versicolor on antibody level. K: normal control; $\mathrm{K}+$ : positive control; K-: negative control; P1, P2, and P3: treated with $C$. versicolor hot water extract before, after, and before-after exposed to $M$. fortuitum. ***) $\mathrm{P}<0.05$ compared to $\mathrm{K}, \mathrm{K}+$, and $\mathrm{K}$ -

In this study, the antibody level indicated an increase in P2 and P3, which were given extract after and before-after a bacterial infection, respectively. Saleh et al. (2017) stated that healthy mice treated with polysaccharide peptides from $C$. versicolor for 2 weeks increased B lymphocytes to produce IgG. Recognition of PSK by the Bcell receptor leads to $\mathrm{B}$ cell activation, clonal proliferation, and eventual differentiation into IgM or IgG plasma and memory B cells. PSK may similarly act on B cells to T cells, 
non-specifically activating them through TLR(s) and leading to a general increase in polyclonal IgM and IgG levels. Yang et al. (2015) showed that compounds of $C$. versicolor have a marked effect on humoral immunity. Murine splenocytes enriched for B lymphocytes and treated with $C$. versicolor extract for 6 days in culture revealed a potent ability to induce IgM production and IgG1 secretion.

Polysaccharide krestin could function as immunomodulatory as it contained 93\% $\beta$-glucan active compound (Kastin, 2013). This compound was found to be related to main immune system receptors, including TLR-2/6, CR3, and dectin-1. Immune cells targeted by $\beta$-glucan are macrophages, NK cells, dendritic cells, neutrophils, and monocytes. Beta-glucan can promote the production of IL-2, IL-6, interferon, immunoglobulin (Ig)-G, also induce T-cell macrophages and lymphocytes (Ley, 2001). In the current study, the administration of polysaccharides from $C$. versicolor hot water extract caused the rise of phagocyte number and activity, IFN- $\gamma$ and antibody levels in concerning exposure of $M$. fortuitum.

\section{CONCLUSION}

We concluded that crude polysaccharides of $C$. versicolor are effective in enhancing immune responses through increased phagocytes, phagocytic activity, IFN- $\gamma$ levels, and antibody levels. The crude polysaccharides also caused TNF$\alpha$ levels to be normal. The use of established techniques for isolating pure polysaccharides has the potential to produce drugs that are more effective and reduce side effects beyond the target.

\section{ACKNOWLEDGEMENT}

This study was financially supported by applied research of pre-eminent college or Penelitian Unggulan Perguruan Tinggi (PUPT), No. 951/ UN3.14/LT/2016, April $4^{\text {th }}, 2016$.

\section{REFERENCES}

Abbas A K., Litchmann A H., Pober J S. (2014) Cellular and Molecular Immunology - $8^{\text {th }}$ edition, Philadelphia: W B. Saunders Company USA.

Atkins B L., Gottlieb T. (2014) Skin and soft tissue infections caused by nontuberculous mycobacteria, Curr. Opin. Infect. Dis. 27(2): 137-145.

Awadasseid A., Hou J., Gamallat Y., Xueqi S., Eugene K D., Hago A M., Bamba D., Meyiah A., Gift C., Xin Y. (2017) Purification, characterization, and antitumor activity of a novel glucan from the fruiting bodies of Coriolus versicolor, Plos One. 12(2): e0171270.

Chan G C., Chan W K., Sze D M. (2009) The effect of $\beta$-glucan on human immune and cancer cells, J. Hematol. Oncol. 2(25): 1-11.

Chen J., Seviour R. (2007) Medicinal importance of fungal $\beta-(1 \rightarrow 3)$, $(1 \rightarrow 6)$-glucans, Mycol. Res. 111(6): 635-652.

Chen K L, Weng B C, Chang M T. (2008) Direct enhancement of the phagocytic and bactericidal capability of abdominal macrophage of chicks by beta-1,3-1,6-glucan, 
Poult. Sci. 87(11): 2242-2249.

D’Elios M., Benagiano M., Bella C., Amedei A. (2011) T-cell response to bacterial agents, J. Infect. Dev. Ctries. 5(9): 640-645

Detrick B., Nagineni C N., Hooks J. (2008) Cytokines: regulators of immune responses and key therapeutic targets. Gorman MRG, Donnenberg AD. (eds). Handbook of Human Immunology, $2^{\text {nd }}$ ed. CRC Press.

Fritz H., Kennedy D A., Ishii M., Fergusson D., Fernandes R., Cooley K., Seely D. (2015) Polysaccharide $\mathrm{K}$ and Coriolus versicolor Extracts for Lung Cancer: A Systematic Review, Integr. Cancer. Ther. 14(3): 201-11.

Goodridge H S., Wolf A J., Underhill D M. (2009) Beta-glucan recognition by the innate immune system, Immunol. Rev. 6(1): 33-34.

Griffith D E., Aksamit T., Brown-Elliott B A., Catanzaro A., Daley C., Gordin F. (2007) An official ATS/IDSA statement: diagnosis, treatment, and prevention of nontuberculous mycobacterial diseases, Am. J. Respir. Crit. Care. Med. 175(4): 367-416.

Kastin A J. (2013) Handbook of biologically active peptides, Academic Press, UK.

Keane J. (2004) Tumor necrosis factor blockers and reactivation of latent tuberculosis, Clin. Infect. Dis. 39(3):300-302.

Kotsirilos V., Sali A., Vitteta L. (2011) A guide to evidence-based integrative and complementary medicine, Elsevier Health Science Sydney.
Lahiri K K., Jena J., Pannicker K K. (2009) Mycobacterium fortuitum infections in surgical wounds, Med. J. Armed. Forces. India. 65(1): 91-92.

Laskin D L., Gardner C R., Laskin, J D. (2010) Phagocytes. Comprehensive Toxicol. 5:133-153.

Ley B M. (2001) Discovery the beta-glucan secret, BL Publications USA.

Meena D K., Das P., Kumar S., Mandal S C., Prusty A K., Singh S K. (2013) Betaglucan: an ideal immunostimulant in aquaculture (a review), Fish. Physiol. Biochem. 39: 431-57.

$\mathrm{Ng}$ T B. (1998) A review of research on the protein-bound polysaccharide (polysaccharopeptide, PSP) from the mushroom Coriolus versicolor (Basidiomycetes: Polyporaceae), Gen Pharmacol. 30(1): 1-4.

Novak M., Vetvicka V. (2008) Beta-glucan, history, and the present: immunomodulatory aspect and mechanisms of action. $J$. Immunotoxicol., 5(1): 47-57.

Paul W E. (2013) Fundamental Immunology, 7th Edition, Lippincott Williams \& Wilkins USA.

Saleh M H., Rashedi I., Keating A. (2017) Immunomodulatory properties of Coriolus versicolor: the role of polysaccharopeptide, Front. Immunol. 8(1087): 1-12.

Scheld W M., Whitley R J., Marra C M. (2014) Infections of the central nervous system, $4^{\text {th }}$ edition, Philadelphia: Wolters Kluwer Health, USA.

Sze D M., Chan G C. (2009) Supplements for immune enhancement in 
hematologic malignancies, Hematology Am. Soc. Hematol. Educ. Program. 2009:313-319.

Taylor P R., Brown G D., Herre J., Williams D L., Willment J A., Gordon S. (2004) The role of SIGNR1 and the beta-glucan receptor (dectin-1) in the non-opsonic recognition of yeast by specific macrophages, J. Immunol. 172(2): 1157-1162.

Ushach I., Albert Zlotnik A. (2016) Biological role of granulocytemacrophage colony-stimulating factor (GM-CSF) and macrophage colony-stimulating factor (M-CSF) on cells of the myeloid lineage, Leukoc Biol. 100(3): 481-489.

Vetvicka V., Oliveira C. (2014) $\beta(1-3)(1-6)$ D-glucans modulate immune status in pigs: potential importance for efficiency of commercial farming, Ann. Transl. Med. 2(2): 16.

Wahyuningsih S P A., Savira N I I., Darmanto W. (2016) Effect of polysaccharide krestin from Coriolus versicolor on phagocytic activity and capacity of Mus musculus exposed
Pseudomonas aeruginosa, Biosaintifika: Journal of Biology \& Biology Education. 8(3): 308-313.

Wahyuningsih S P A., Pramudya M., Putri I P., Savira N I I., Winarni D., Darmanto W. (2018) Crude polysaccharides from okra pods (Abelmoschus esculentus) grown in Indonesia enhance the immune response due to bacterial infection, Adv. Pharmacol. Sci., 2018(4) ID 8505383.

Yang S F., Zhuang T F., Si Y M., Qi K Y., Zhao J. (2015). Coriolus versicolor mushroom polysaccharides exert immunoregulatory effects on mouse B cells via mem-brane Ig and TLR-4 to activate the MAPK and NFkappaB signaling pathways, Mol. Immunol. 64(1): 144-51.

Yu J., Cong L., Wang C., Li H., Zhang C., Guan X., Liu P., Xie Y., Chen J., Sun J. (2018). Immunomodulatory effect of Schisandra polysaccharides in cyclophosphamide- induced immune-compromised mice, Exp. Ther. Med. 15(6): 4755-4762. 